\title{
Effects of Fruit By-product Extracts on Blood Characteristics, Antioxidant Activity, and Immune Response in Pigs
}

\author{
Jun Cheol Park ${ }^{1}$, Se Hun Lee ${ }^{1}$, Sung Kwon Park ${ }^{1}$, Joon Ki Hong ${ }^{1}$, Zheng Fan Zhang ${ }^{2}$, Jin Ho Cho ${ }^{2}$ \\ and In $\mathrm{Ho} \mathrm{Kim}^{2} *$ \\ ${ }^{1}$ National Institute of Animal Science, R.D.A, South Korea, ${ }^{2}$ Department of Animal Resource \& Science, \\ Dankook University, Cheonan, Choognam, 330-714, South Korea
}

\begin{abstract}
This experiment was conducted to determine the effects of extracts from fruit by-products on the blood characteristics, antioxidant activities, and immune response to Escherichia coli lipopolysaccharide (LPS) in growing pigs. A total of 96 pigs [(Landrace $\times$ Yorkshire $) \times$ Duroc] with an initial BW of $27.94 \pm 0.92 \mathrm{~kg}$ were used in a 6-week feeding trial. The pigs were randomly placed into one of four treatment groups with six replications (four pigs per replication) per treatment according to their initial BW. Treatments were: 1) CON (basal diet), 2) PRO (CON $+0.5 \%$ procyanidin), 3) HES (CON $+0.5 \%$ hesperetin), 4) TAN $(\mathrm{CON}+0.5 \%$ tannin). At the end of the sixth week, five pigs (total 20 pigs, BW $=27.94 \pm 0.92 \mathrm{~kg}$ ) were selected from each treatment and injected with LPS $(100 \mu \mathrm{g} / \mathrm{kg}$ of BW). Blood samples were collected $3 \mathrm{~h}$ after LPS injection to assess anti-oxidative and inflammatory responses. After the LPS challenge, the concentration of serum cholesterol decreased with fruit by-product treatment compared with $\mathrm{CON}(p<0.05)$. The administration of TAN increased the concentration of blood total protein compared with the CON group $3 \mathrm{~h}$ after LPS challenge $(p<0.05)$. The albumin concentration was also higher with PRO treatment compared to HES treatment $(p<0.05)$. The concentration of $\operatorname{IgM}$ was increased by fruit by-product supplementation at 0 and $3 \mathrm{~h}(p<0.05)$. In addition, IgG concentration was higher in PRO, HES, and TAN treatments compared to CON treatment at $0 \mathrm{~h}$, and IgG concentrations were also higher in the HES group compared to the CON group at $3 \mathrm{~h}(p<0.05)$. The concentration of $\operatorname{IgA}$ also increased with fruit by-product treatments at $3 \mathrm{~h}(p<0.05)$. In conclusion, dietary supplementation with fruit by-products may moderate the immune response after a LPS challenge in growing pigs.
\end{abstract}

(Key words : Antioxidant capability, Blood characteristics, Growing pigs, Lipopolysaccharide, Immune response)

\section{INTRODUCTION}

During the summer seasons, fruit by-products from grapes, citrus fruits, and persimmons are abundant in South Korea. Many researchers have reported that extracts from grape seeds possess antioxidant, anti-inflammatory, and antimicrobial activity (Jayaprakasha et al., 2003; Vigna et al., 2003). Lien et al. (2007) reported that flavonoids in grape extracts are components that could promote health. Han et al. (2008) reported that high concentrations of procyanidins in grape seeds contribute a hydrogen donation ability that exerts a strong antioxidant effect. Brenes et al. (2008) demonstrated that polyunsaturated fatty acids (PUFA) in grape pomace powder inhibit oxidation in the chicken breast.

Larrauri et al. (1996) reported that citrus peels contained high levels $(904 \mu \mathrm{g} / \mathrm{g})$ of flavonoids (e.g., hesperetin), which contain numerous hydroxyl $(-\mathrm{OH})$ groups, and act as strong antioxidants by supplying hydrogen atoms to quench free radicals (Deng et al., 1997; Jeon et al., 2001). Persimmons also contain many medicinally bioactive compounds, such as carotenoids, tannins, and flavonoids (Mallavadhani et al., 1998). The concentration of carotenoids and polyphenols are also relatively higher in the peel than the pulp(Kawase et al., 2003).

Despite these previous studies, little work has been conducted to evaluate the effects of fruit by-products on antioxidant activities and immune responses in growing pigs. We hypothesized that the application of fruit by-products could ease oxidative stress caused by Escherichia coli in growing pigs. We therefore investigated the effects of procyanidin, hesperetin, and tannin on the blood characteristics, antioxidant activities, and immune responses under an inflammatory challenge in growing pigs.

* Corresponding author: Professor In Ho Kim, Department of Animal Resource \& Science, Dankook University, Cheonan, Choongnam, 330-714, Korea. Tel: 82-41-550-3652, Fax: 82-41-565-2949, E-mail: inhokim@dankook.ac.kr 


\section{MATERIALS AND METHODS}

\section{Preparation of fruit by-products}

The fruit by-product extracts used in this study were supplied from SINE-BIO Inc. (Seongman, Korea). Briefly, fruit by-product extracts were collected and sterilized as described by Hwang et al. (2011). Procyanidin was extracted using a mixture of acetone/water/acetic acid (v/v/v 70/29.5/ $0.5)$, and filtered and dried under reduced pressure using a rotary evaporator at $40^{\circ} \mathrm{C}$. It was further dried using a freeze drier and $70 \%$ acetone extracts were obtained. The extracts were separated using n-hexane, and further separated using an open column chromatography packed with silica gel. The stationary phase consisted of Sephadex LX-20 and the mobile phase consisted of a mixture of methanol and water (v/v 20/80).

Citrus peel was ground to a powder and soaked in methanol for over a day. The methanol extracts were filtered and dried under reduced pressure using a rotary evaporator at $40^{\circ} \mathrm{C}$. A $\mathrm{C} 18$ column (Phenomenex, Torance, CA, $250 \times$ $4.6 \mathrm{~mm}$ ) was used for reverse-phase with a mobile phase consisting of a mixture of acetonitrile and water $(20: 80 \mathrm{v} / \mathrm{v})$. The flow rate was $1.0 \mathrm{ml} / \mathrm{min}$ and the sample was detected at $283 \mathrm{~nm}$.

Persimmon peel was ground to a powder and soaked in $50 \%$ aqueous methanol (water : methanol $=50 / 50$ ) over a day. The 50\% aqueous methanol extracts were filtered and dried under reduced pressure using a rotary evaporator at $40{ }^{\circ} \mathrm{C}$. A C18 column (Phenomenex, Torance, CA, $250 \times 4.6 \mathrm{~mm}$ ) was used for reverse-phase with a mobile phase consisting of a mixture of methanol and $0.2 \%$ phosphate solution $(10: 90 \mathrm{v} / \mathrm{v})$. The flow rate was $1.0 \mathrm{ml} / \mathrm{min}$ and the sample was detected at $280 \mathrm{~nm}$.

\section{Animal management and experimental diets}

The experimental protocol used in this study was approved through the Animal Care and Use Committee of Dankook University. All pigs were housed in an environmentally controlled facility with slatted plastic flooring and a mechanical ventilation system. Each pen was equipped with a one-sided, stainless-steel self-feeder and a nipple drinker that allowed ad libitum access to feed and water. All constituents of the diets were formulated in a mash form to meet or exceed the nutrient requirements (NRC, 1998) for 20 to $50 \mathrm{~kg}$ of $\mathrm{BW}$ growing pigs (Table 1).

\section{(1) Experimental animals and design}

A total of 96 pigs [(Landrace $\times$ Yorkshire $) \times$ Duroc, BW $=$ $27.94 \pm 0.92 \mathrm{~kg}$ ] were used in a six-week experiment. They were randomly assigned to one of four treatments with sixreplications (four pigs per replication) per treatment according to their initial BW. Treatments were: 1) CON (basal diet), 2) $\mathrm{PRO}(\mathrm{CON}+0.5 \%$ procyanidin $), 3)$ HES $(\mathrm{CON}+0.5 \%$ hesperetin), and 4) TAN (CON $+0.5 \%$ tannin).

After the feeding trial, 20 pigs were selected from the four treatment groups (five pigs per treatment) to conduct subsequent challenge trials. The average BW of the 20 pigs was $49.06 \pm 4.79 \mathrm{~kg}$. Pigs were housed in an environmentally controlled room $\left(24\right.$ to $\left.27^{\circ} \mathrm{C}\right)$ and allowed free access to feed and water during this period. No vaccines or antibiotics were administered to these pigs before or throughout the study. All of the pigs in each dietary treatment were injected with E. coli (serotype O111: B4) LPS (Sigma Chemical Co., St. Louis, MO) at a level of $100 \mu \mathrm{g} / \mathrm{kg} \mathrm{BW}$. The dosage of LPS used was based on the results of previous studies (Matteri et al., 1998; Wright et al., 2000). The LPS solution $(1 \mathrm{mg} / \mathrm{ml})$ was prepared via the dilution of the LPS with phosphate buffered saline (PBS).

\section{(2) Sampling and measurements}

Blood samples were collected from all pigs via jugular venipuncture at $\mathrm{d} 0, \mathrm{~d} 42$, and $3 \mathrm{~h}$ after the administration of LPS. Blood samples were collected into a non-heparinized vacuum tube (Becton Dickinson Vacutainer Systems, Franklin Lakes, NJ) for the evaluation of sera. Whole blood samples were subsequently centrifuged for $15 \mathrm{~min}$ at $3000 \times \mathrm{g}$ and the sera harvested. Thereafter, the samples were frozen and stored at $-20^{\circ} \mathrm{C}$ until further analysis. The creatinine, glutamic oxalate transaminases (GOT), lactate dehydrogenase (LD), cholesterol, total proteins (TP), albumin, and blood urea nitrogen (BUN) concentrations in the sera were analyzed using an automatic blood analyzer(COBAS MIRA plus, ROCHE diagnostics. Block Scientific, Inc. Bochemia, NY. USA). Serum cortisol was determined using a radioimmunoassay (RIA) kit (Siemens, USA), TNF-a was evaluated using a commercially available enzyme immune assay(EIA) kit (R\&D, US), and IL-6 was evaluated using a commercially available enzyme immune assay (EIA) kit (Raybiotech, US). Serum immunoglobulin $A, G$, and $M$ concentrations were evaluated using commercially available ELISA Starter 
Table 1. Compositions of experimental diets (as-fed basis)

\begin{tabular}{|c|c|c|c|c|}
\hline Item & $\mathrm{CON}^{1)}$ & $\mathrm{PRO}^{1)}$ & $\mathrm{HES}^{1)}$ & TAN $^{1)}$ \\
\hline \multicolumn{5}{|l|}{ Ingredients, \% } \\
\hline Corn & 47.01 & 46.71 & 46.71 & 46.71 \\
\hline wheat & 11.15 & 11.15 & 11.15 & 11.15 \\
\hline Soybean meal & 23.10 & 22.90 & 22.90 & 22.90 \\
\hline DDGS & 8.00 & 8.00 & 8.00 & 8.00 \\
\hline Rice bran & 1.00 & 1.00 & 1.00 & 1.00 \\
\hline Tallow & 3.23 & 3.23 & 3.23 & 3.23 \\
\hline Molasses & 3.00 & 3.00 & 3.00 & 3.00 \\
\hline Dicalcium phosphate & 0.25 & 0.25 & 0.25 & 0.25 \\
\hline Limestone & 1.68 & 1.68 & 1.68 & 1.68 \\
\hline Salt & 0.30 & 0.30 & 0.30 & 0.30 \\
\hline Choline chloride & 0.08 & 0.08 & 0.08 & 0.08 \\
\hline L-Lysine & 0.83 & 0.83 & 0.83 & 0.83 \\
\hline DL-Methionine & 0.05 & 0.05 & 0.05 & 0.05 \\
\hline L-Threonine & 0.02 & 0.02 & 0.02 & 0.02 \\
\hline Vitamin premix ${ }^{2)}$ & 0.20 & 0.20 & 0.20 & 0.20 \\
\hline Trace mineral premix ${ }^{3)}$ & 0.10 & 0.10 & 0.10 & 0.10 \\
\hline Procyanidin & - & 0.50 & - & - \\
\hline Hesperidin & - & - & 0.50 & - \\
\hline Tannin & - & - & - & 0.50 \\
\hline \multicolumn{5}{|l|}{ Chemical analysis value } \\
\hline $\mathrm{DE}, \mathrm{kcal} / \mathrm{kg}$ & 3380 & 3350 & 3360 & 3350 \\
\hline Crude protein, $\%$ & 19.00 & 18.87 & 18.91 & 18.85 \\
\hline Crude fat, $\%$ & 6.49 & 6.33 & 6.40 & 6.37 \\
\hline Lys, $\%$ & 0.94 & 0.92 & 0.93 & 0.91 \\
\hline $\mathrm{Ca}, \%$ & 0.80 & 0.80 & 0.80 & 0.80 \\
\hline Total P, \% & 0.63 & 0.63 & 0.63 & 0.63 \\
\hline
\end{tabular}

1) Abbreviation: CON (basal diet), PRO (CON + 0.5\% procyanidin), HES (CON $+0.5 \%$ tannin), TAN (CON $+0.5 \%$ tannin).

2) Provided per kg of complete diet: vitamin A, 4,000 IU; vitamin $\mathrm{D}_{3}, 800 \mathrm{IU}$; vitamin E, $171 \mathrm{IU}$; vitamin K, 2 mg; riboflavin, 4 mg; niacin, 20 $\mathrm{mg}$; thiamine, $4 \mathrm{mg}$; d-pantothenic, $11 \mathrm{mg}$; choline, $166 \mathrm{mg}$; biotin, $0.08 \mathrm{mg}$; and vitamin $\mathrm{B}_{12}, 16 \mu \mathrm{g}$

${ }^{3)}$ Provided per kg of complete diet: $\mathrm{Cu}\left(\right.$ as $\left.\mathrm{CuSO}_{4} \cdot 5 \mathrm{H}_{2} \mathrm{O}\right), 15 \mathrm{mg} ; \mathrm{Fe}\left(\right.$ as $\left.\mathrm{FeSO}_{4} \cdot 7 \mathrm{H}_{2} \mathrm{O}\right), 80 \mathrm{mg} ; \mathrm{Zn}\left(\right.$ as $\mathrm{ZnSO}$ ), $\left.56 \mathrm{mg} ; \mathrm{Mn}_{(\mathrm{MnO}}\right), 74 \mathrm{mg} ; \mathrm{I}$ (as $\mathrm{KI}), 0.3 \mathrm{mg}$; $\mathrm{Co}\left(\right.$ as $\left.\mathrm{CoSO}_{4} \cdot 5 \mathrm{H}_{2} \mathrm{O}\right), 0.5 \mathrm{mg}$; and $\mathrm{Se}\left(\right.$ as $\left.\mathrm{Na}_{2} \mathrm{SeO}_{3} \cdot 5 \mathrm{H}_{2} \mathrm{O}\right), 0.4 \mathrm{mg}$.

Accessory kits (Bethyl Laboratories, Inc. Montgomery, TX. USA). The absorbance was read at $450 \mathrm{~nm}$ using a microplate reader (Versamax, Molecular Devices, Inc. Sunnyvale, CA. US).

The effect of fruit by-products on 1,1-diphenyl-2-picrylhydrazyl (DPPH) radicals was estimated according to the method of Lim et al. (2000). In brief, after $0.5 \mathrm{ml}$ of 0.5 $\mathrm{mM}$ DPPH was mixed with $0.5 \mathrm{ml}$ of $100 \mathrm{mM}$ Tris- $\mathrm{HCl}$ buffer, $0.05 \mathrm{ml}$ of pig sera was added for $15 \min \left(37^{\circ} \mathrm{C}\right)$. Thereafter, 1 mlof chloroform was added into the solution, and the absorbance was measured at $517 \mathrm{~nm}$ after a 3,000 rpm centrifugation for $10 \mathrm{~min}$. Superoxide dismutase (SOD) activity in sera was determined according to the method of Marklund and Marklund (1974). After mixing $0.1 \mathrm{ml}$ of serum in $1.5 \mathrm{ml}$ Tri-HCl buffer, $0.05 \mathrm{ml}$ of $5 \mathrm{mM}$ pyrogallol was added into the serum solution at $25^{\circ} \mathrm{C}$ for a $30 \mathrm{~min}$ reaction in water-bath. The absorbance was measured at 420 $\mathrm{nm}$, and the SOD-like activity was calculated using the following formula:

SOD-like activity, \%= [control absorbance - (sample absorbance - blank absorbance)] / control absorbance $\times 100$.

\section{Statistical analysis}


All the data were analyzed by ANOVA using the General Linear Models (GLM) procedure of SAS (SAS Institute, 2008), with the pen being defined as the experimental unit. Differences among treatments were separated by Duncan's multiple range tests. The results were expressed as the least square means $\pm \mathrm{SEM}$. Probability values less than 0.05 were considered significant.

\section{RESULTS}

\section{Blood characteristics}

After LPS challenge, the serum cholesterol concentration with HES and TAN treatments were lower $(p<0.05)$ compared with CON and PRO treatments (Table 2). In addition, the total protein concentration increased with TAN treatment compared with $\mathrm{CON}$ treatment $(p<0.05)$. No differences were observed in GOT, LD, and BUN concentrations among all treatments throughout the experiment.

\section{Immune response}

Dietary supplementation with fruit by-products increased the concentrations of $\operatorname{IgM}$ and $\operatorname{IgG}$ at $\mathrm{d} 42(p<0.05)$ (Table 3). Pigs fed the PRO, HES, and TAN diets had higher IgM and $\operatorname{IgA} 3 \mathrm{~h}$ after the LPS challenge $(p<0.05)$. The IgG concentration also increased with HES treatment compared with CON diet $3 \mathrm{~h}$ after the LPS challenge $(p<0.05)$. The serum concentrations of cortisol, TNF-a, and IL-6 were unaffected by dietary treatments $(p>0.05)$ (Table 4$)$.

Table 2. The effect of fruit by-product extracts on blood profiles in growing pigs ${ }^{1)}$

\begin{tabular}{|c|c|c|c|c|c|}
\hline Items, $\%$ & $\mathrm{CON}$ & PRO & HES & TAN & SEM $^{2)}$ \\
\hline \multicolumn{6}{|l|}{ Creatinine $(\mathrm{mg} / \mathrm{dL})$} \\
\hline $\mathrm{d} 0$ & 2.1 & 1.8 & 1.4 & 1.5 & 0.3 \\
\hline $\mathrm{d} 42$ & $1.9^{\mathrm{ab}}$ & $2.3^{\mathrm{a}}$ & $1.1^{\mathrm{b}}$ & $1.4^{\mathrm{b}}$ & 0.3 \\
\hline $\mathrm{d} 42+$ LPS $3 \mathrm{hr}$ & 2.2 & 2.4 & 1.8 & 2.1 & 0.3 \\
\hline \multicolumn{6}{|l|}{ GOT (U/L) } \\
\hline $\mathrm{d} 0$ & 50.8 & 79.3 & 77.8 & 73.45 & 10 \\
\hline d 42 & 52.7 & 45.5 & 41.0 & 36.8 & 9.7 \\
\hline $\mathrm{d} 42+$ LPS $3 \mathrm{hr}$ & 55.0 & 76.5 & 56.0 & 53.8 & 9.3 \\
\hline \multicolumn{6}{|l|}{$\mathrm{LD}(\mathrm{mg} / \mathrm{dL})$} \\
\hline $\mathrm{d} 0$ & 1,502 & 1,625 & 1,418 & 1,376 & 105 \\
\hline d 42 & 674 & 799 & 523 & 548 & 55 \\
\hline $\mathrm{d} 42+$ LPS $3 \mathrm{hr}$ & 1,089 & 1,386 & 632 & 635 & 36 \\
\hline \multicolumn{6}{|l|}{ Cholesterol (mg/dL) } \\
\hline $\mathrm{d} 0$ & 103.3 & 104.0 & 98.3 & 94.0 & 4.6 \\
\hline d 42 & 97.8 & 106.4 & 105.3 & 97.8 & 4.7 \\
\hline $\mathrm{d} 42+$ LPS $3 \mathrm{hr}$ & $142.0^{\mathrm{a}}$ & $136.8^{\mathrm{a}}$ & $98.3^{\mathrm{b}}$ & $86.5^{\mathrm{b}}$ & 5.0 \\
\hline \multicolumn{6}{|c|}{ Total proteins $(\mathrm{g} / \mathrm{dL})$} \\
\hline d 0 & 5.4 & 15.4 & 5.5 & 5.5 & 4.1 \\
\hline $\mathrm{d} 42$ & $6.5^{\mathrm{b}}$ & $7.4^{\mathrm{a}}$ & $6.7^{\mathrm{b}}$ & $6.9^{\mathrm{ab}}$ & 0.2 \\
\hline $\mathrm{d} 42+$ LPS $3 \mathrm{hr}$ & $6.3^{\mathrm{b}}$ & $6.6^{\mathrm{ab}}$ & $6.6^{\mathrm{ab}}$ & $6.9^{\mathrm{a}}$ & 0.1 \\
\hline \multicolumn{6}{|l|}{ Albumin (g/dL) } \\
\hline $\mathrm{d} 0$ & 3.2 & 3.3 & 3.2 & 3.1 & 0.1 \\
\hline $\mathrm{d} 42$ & $3.2^{\mathrm{ab}}$ & $3.4^{\mathrm{a}}$ & $2.9^{\mathrm{c}}$ & $3.1^{\mathrm{bc}}$ & 0.1 \\
\hline $\mathrm{d} 42+$ LPS $3 \mathrm{hr}$ & 3.2 & 3.1 & 3.0 & 3.2 & 0.1 \\
\hline \multicolumn{6}{|l|}{$\overline{\mathrm{BUN}}(\mathrm{mg} / \mathrm{dL})$} \\
\hline $\mathrm{d} 0$ & 13.3 & 16.0 & 14.8 & 15.0 & 2.0 \\
\hline d 42 & 18.5 & 21.0 & 16.3 & 18.0 & 3.0 \\
\hline d $42+$ LPS $3 \mathrm{hr}$ & 21.3 & 19.8 & 18.8 & 18.3 & 1.9 \\
\hline
\end{tabular}

1) Abbreviation: CON (basal diet), PRO (CON $+0.5 \%$ procyanidin), HES (CON $+0.5 \%$ tannin), TAN (CON $+0.5 \%$ tannin).

${ }^{2)}$ Standard error of the mean.

${ }^{\mathrm{a}, \mathrm{b}, \mathrm{c}}$ Means in the same row with different superscripts differ $(p<0.05)$. 
Park et al. ; Effect of Fruit By-product Extracts in Growing Pigs

Table 3. The effect of fruit by-product extracts on immune response in growing pigs ${ }^{1)}$

\begin{tabular}{|c|c|c|c|c|c|}
\hline Items, $\mathrm{mg} / \mathrm{mL}$ & $\mathrm{CON}$ & PRO & HES & TAN & $\mathrm{SEM}^{2)}$ \\
\hline \multicolumn{6}{|c|}{ 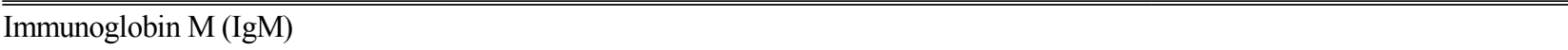 } \\
\hline $0 \mathrm{~h}$ & $3.33^{\mathrm{b}}$ & $14.88^{\mathrm{a}}$ & $11.67^{\mathrm{a}}$ & $15.08^{\mathrm{a}}$ & 1.10 \\
\hline $3 \mathrm{~h}$ & $2.28^{\mathrm{b}}$ & $11.99^{\mathrm{a}}$ & $11.31^{\mathrm{a}}$ & $12.60^{\mathrm{a}}$ & 0.74 \\
\hline \multicolumn{6}{|c|}{ Immunoglobin G(IgG) } \\
\hline $0 \mathrm{~h}$ & $5.36^{\mathrm{b}}$ & $8.43^{\mathrm{a}}$ & $8.45^{\mathrm{a}}$ & $8.17^{\mathrm{a}}$ & 0.76 \\
\hline $3 \mathrm{~h}$ & $7.03^{\mathrm{b}}$ & $9.24^{\mathrm{ab}}$ & $10.35^{\mathrm{a}}$ & $9.08^{\mathrm{ab}}$ & 0.73 \\
\hline \multicolumn{6}{|c|}{ Immunoglobin A (IgA) } \\
\hline $0 \mathrm{~h}$ & 1.97 & 2.43 & 2.05 & 2.31 & 0.17 \\
\hline $3 \mathrm{~h}$ & $0.84^{\mathrm{b}}$ & $2.01^{\mathrm{a}}$ & $1.84^{\mathrm{a}}$ & $1.73^{\mathrm{a}}$ & 0.12 \\
\hline \multicolumn{6}{|c|}{$\begin{array}{l}\left.{ }^{1)} \text { Abbreviation: } \mathrm{CON} \text { (basal diet), PRO (CON }+0.5 \% \text { procyanidin), } \mathrm{HES}(\mathrm{CON}+0.5 \% \operatorname{tannin}) \text {, TAN (CON }+0.5 \% \operatorname{tannin}\right) \text {. } \\
{ }^{2)} \text { Standard error of the means. }\end{array}$} \\
\hline \multicolumn{6}{|c|}{$\begin{array}{l}\text { Table 4. The effect of fruit by-product extracts on serum cortisol, TNF-a, and IL-6 concentrations } 3 \mathrm{hr} \text { aft } \\
\text { challenge with lipopolysaccharide in growing pigs }{ }^{1)}\end{array}$} \\
\hline Items & $\mathrm{CON}$ & PRO & HES & TAN & $\mathrm{SEM}^{2)}$ \\
\hline Cortisol $(\mu \mathrm{g} / \mathrm{dL})$ & 12.3 & 16.9 & 11.8 & 11.9 & 4.4 \\
\hline $\mathrm{TNF}^{-} \alpha(\mathrm{pg} / \mathrm{mL})$ & 364.4 & 879.6 & 721.4 & 252.4 & 26 \\
\hline IL-6 (pg/mL) & 5,644 & 6,773 & 5,416 & 4,142 & 22 \\
\hline
\end{tabular}

1) Abbreviation: $\mathrm{CON}$ (basal diet), $\mathrm{PRO}(\mathrm{CON}+0.5 \%$ procyanidin), $\mathrm{HES}(\mathrm{CON}+0.5 \%$ tannin $)$, TAN $(\mathrm{CON}+0.5 \%$ tannin $)$.

2) Standard error of mean.

Table 5. The effect of fruit by-product extracts on antioxidant activities in growing pigs ${ }^{1)}$

\begin{tabular}{lllllc}
\hline Items, $\%$ & CON & PRO & HES & TAN & SEM $^{2)}$ \\
\hline \hline DPPH free radical scavenging & 42.5 & 41.0 & 39.6 & 39.4 & 3.5 \\
SOD-liked activity & $25.1^{\mathrm{b}}$ & $55.9^{\mathrm{a}}$ & $39.4^{\mathrm{ab}}$ & $28.7^{\mathrm{ab}}$ & 9.2 \\
\hline
\end{tabular}

1) Abbreviation: CON (basal diet), $\mathrm{PRO}(\mathrm{CON}+0.5 \%$ procyanidin), $\mathrm{HES}(\mathrm{CON}+0.5 \%$ tannin $), \mathrm{TAN}(\mathrm{CON}+0.5 \%$ tannin $)$.

2) Standard error of the mean.

${ }^{a, b}$ Means in the same row with different superscripts differ $(p<0.05)$.

\section{Antioxidant activity}

At $\mathrm{d} 42$, no difference was observed in DPPH free radical scavenging activity among treatments $(p>0.05)$ (Table 5). However, the SOD-like activity increased with PRO treatment compared with the CON treatment $(p<0.05)$.

\section{DISCUSSION}

The serum concentration of creatinine is the most widely used and commonly accepted measure of renal function in clinical medicine (Chen et al., 2003). Polyphenolic flavonoids in fruits are known for their ability to inhibit platelet aggregation and polymorphonuclear leukocyte function in vivo. The concentration of leucocytes was significantly increased by supplementation of a flavonoid-rich extract of orange peel $(5 \mathrm{mg} / 100 \mathrm{~g}$ body weight) in guinea-pigs (Wilson et al., 1976).

In the current study, the concentrations of total proteins and albumin were increased with procyanidin and tannin treatments. Nitric oxide free radicals $\left(\mathrm{NO}^{\circ}\right)$ display a high affinity for the heme group of some proteins (Staedler et al., 1995). The production of NO is increased by various pro-inflammatory factors such as LPS challenge, ultraviolet irradiation, and ozone (Pendino et al., 1993; Warren, 1994). Virgili et al. (1998) reported that procyanidins could decrease the massive amounts of $\mathrm{NO}$ by depressing the expression of a distinct isoform of nitric oxide synthase. Thus, this may 
explain how $\mathrm{NO}^{*}$ combined proteins are released from the heme group.

In this study, the concentration of cholesterol decreased with HES and TAN treatments compared with CON and PRO treatments after the challenge with LPS. Other reports have also demonstrated that dietary supplementation with hesperetin decreases serum cholesterol levelin rats (Lee et al., 1999; Kim et al. 2003). This might be attributed to its ability to decrease the activities of the liver cholesterol synthesis (and rate limiting) enzymes HMG-COA reductase and acyl-COA : cholesterol acyltransferase (Lee et al., 1999; Kim et al. 2003).

The inflammatory and acute phase responses occurring after challenge with endotoxic materials, such as LPS, have been characterized in pig models (Johnson, 1997; Wright et al., 2000). Pro-inflammatory cytokines, such as tumor necrosis factor a (TNF-a), interleukin-6 (IL-6), as well as cortisol, are reportedly elevated in plasma in response to peripheral lipopolysaccharide (LPS) injection in weaned pigs (Webel et al., 1997). In this study there was no effect observed in the concentrations of cortisol, TNF-a, and IL-6 by dietary supplementation, but the consumption of fruit by-products increased $\operatorname{IgM}, \operatorname{IgG}$, and $\operatorname{IgA}$ levels in sera after the LPS challenge.

Potent anti-inflammatory properties of procyanidins have been demonstrated on experimental inflammation in rats and mice (Marnewick et al., 2003; Marnewick et al., 2005). Terra et al. (2007) reported that grape-seed procyanidins enhance anti-inflammatory activity by decreasing the overproduction of $\mathrm{NO}$ and prostaglandin $\mathrm{E}_{2}$ through the $\mathrm{NFkB}$ inhibiting signaling pathway. Certain flavonoids possess potent inhibitory activities on several enzyme systems, such as protein kinase $\mathrm{C}$, protein tyrosine kinases, and phospholipase A2 by redox activity.

Procyanidin and flavonoids are composed of aromatic rings with hydroxyl groups and potentially quench free radicals by forming resonance-stabilized phenoxyl radicals (Rice-Evans et al., 1996). Antioxidant activities were evaluated by assessing DPPH (1,1-diphenyl-2-picrylhydrazyl) radical scavenging activity (RSA) and SOD (superoxide dismutase) activity. Free radicals and active oxygen species play a causative role in such diseases as cancer and atherosclerosis. They also cause protein modification, enzyme inactivation, and DNA damage through the oxidation of lipids, proteins, and DNA (Miyake et al., 2003). SOD and GPX (glutathione peroxidase) are important antioxidant defense. These enzymes are involved in the clearance of superoxide and $\mathrm{H}_{2} \mathrm{O}_{2}$ to maintain the structure and function of biological membranes (McCord, 2000).

In our study, SOD-like activity improved through dietary supplementation with procyanidin. In previous studies, the main mechanisms of procyanidin's antioxidant activity were attributed to direct free radical scavenging, transition metal chelation, and the maintenance of endogenous antioxidants, such as the glutathione and superoxide dismutase systems (Touriño et al., 2005). Zhishen et al. (1999) also reported that flavonoids could directly to scavenge $\mathrm{O}_{2}{ }^{\cdot}$ and $\mathrm{OH}^{*}$ by single electron transfer. However, the free radical scavenging activity was unaffected by supplementation with fruit by-products in diets. This lack of effect could be due to many factors, such as where the oxidation of key molecules (e.g., lipids, proteins, DNA) takes place (Frankel, 1995). Moreover, the biological modification of procyanidin after ingestion in animals may induce compounds in the supplementation mixture that may not eventually exert antioxidant activity (Packer et al., 1999).

\section{CONCLUSION}

In conclusion, our results indicate that dietary supplementation with fruit by-products may improve antioxidant activities and moderate immune responses after LPS challenge in growing pigs.

\section{ACKNOWLEDGEMENTS}

This work was carried out with the support from the Cooperative Research Program for Agriculture Science \& Technology Development (Project No. PJ009340) of the Rural Development Administration, Republic of Korea.

\section{REFERENCES}

Brenes, A., Viveros, A., Goni, I., Centeno, C., Sayago-Ayerdy, S. G., Arija, I. and Saura-Calixto, F. 2008. Effect of Grape Pomace Concentrate and Vitamin E on Digestibility of Polyphenols and Antioxidant Activity in Chickens. Poult. Sci. 87:307-316.

Chen, S. T., Peng, S. J. and Chen, J. R. 2003. Effects of dietary protein on renal function and lipid metabolism in five-sixths nephrectomized rats. Br. J. Nutr. 89:491-497.

Deng, W., Fang, X. and Wu, J. 1997. Flavonoids function as 
antioxidants: By scavenging reactive oxygen species or by chelating iron. Radiat. Phys. Chem. 50:271-276.

Frankel, E. 1995. Nutritional benefits of flavonoids. International conference on food factors: Chemistry and cancer prevention, Hamamatsu, Japan. Abstracts, C6-2.

Han, J. Y., Sung, J. H., Kim, D. J., Jeong, H. S. and Lee, J. S. 2008. Inhibitory Effect of Methanol Extract and Its Fractions from Grape Seeds on Mushroom Tyrosinase. J. Korean Soc Food Sci. Nutr. 37:1679-1683.

Hwang, D. S., Shin, S. Y., Lee, Y. G., Hyun, J. Y., Yong, Y. J., Park, J. C., Lee, Y. H. and Lim, Y. H. 2011. A compound isolated from Schisandra chinensis induces apoptosis. Bioorg. Med. Chem. Lett. 21:6054-6057.

Jayaprakasha, G. K., Tamil, S. and Sakariah, K. K. 2003. Antibacterial and antioxidant activities of grape (Vitis vinifera) seed extracts. Food Res. Int. 36:117-122.

Jeon, S. M., Bok, S. H., Jang, M. K., Lee, M. K., Nam, K. T., Park, Y. B., Rhee, S. J. and Chio, M. S. 2001. Antioxidative activity of naringin and lovastatin in high cholesterol-fed rabbits. Life Sci. 69:2855-2866.

Johnson, R. W. 1997. Inhibition ofgrowth by pro-inflammatory cytokines: an integrated view. J. Anim. Sci. 75:1244-1255.

Kawase, M., Motohashi, N., Satoh, K., Sakagami, H., Nakashima, H., Tani, S., Shirataki, Y., Kurihara, T., Spengler, G., Wolfard, K. and Molnár, J. 2003. Biological activity of persimmon (Diospyros kaki) peel extracts. Phytother Res. 17:495-500.

Kim, H. K., Jeong, T. S., Lee, M. K., Park, Y. B. and Choi, M. S. 2003. Lipid-lowering efficacy of hesperetin metabolites in high-cholesterol fed rats. Clin. Chim. Acta. 327:129-137.

Larrauri, J. A., Ruperez, P., Bravo, L. and Saura-Calixto, F. 1996. High dietary fibre powdersfrom orange and lime peels: Associated polyphenols and antioxidant capacity. Food Res. Int. 29:757-762.

Lee, S. H., Jeong, T. S., Park, Y. B., Kwon, Y. K., Choi, M. S. and Bok, S. H. 1999. Hypocholesterolemic effect of hesperetin mediated by inhibition of 3-hydroxy-3-methylgultaryl coenzyme a reductase and acyl coenzyme A: Cholesterol acyltransferase in rats fed high cholesterol diet. Nutr. Res. 19:1245-1258.

Lien, T. F., Yeh, H. S. and Su, W. T. 2007. Effect of adding extracted hesperetin, naringenin and pectin on egg cholesterol, serum traits and antioxidant activity in laying hens. Arch. Ani. Nutr. 62:33-43.

Lim, B. O., Seo, T. W., Shin, H. M., Park, D. K., Kim, S. U., Cho, K. H. and Kim, H. C. 2000. Effect of Betulae Plantyphtllae Cortex on free radical in diabetic rats induced by streptozotocin. Korean J. Herbology. 15:69-77.
Mallavadhani, U. V., Panda, A. K. and Rao, Y. R. 1998. Pharmacology and chemotaxonomy of Diospyros. Phytochemistry. 49:901-951.

Marklund, S. and Marklund G. 1974. Involvement of the superoxide anion radical in the autoxidation of pyrogallol and a convenient assay for superoxide dismutase. Eur. J. Biochem. 47:469-474.

Marnewick, J. L., Joubert, E., Swart, P., Westhuizen, V. D. F. and Gelderblom, W. C. 2003. Modulation of hepatic drug metabolizing enzymes and oxidative status by rooibos (Aspalathus linearis) and honeybush (Cyclopia intermedia), green and black (Camellia sinensis) teas in rats. J. Agric. Food Chem. 51:8113-8119.

Marnewick, J. L., Joubert, E., Joseph, S., Swanevelder, S., Swart, P. and Gelderblom, W. 2005. Inhibition of tumour promotion in mouse skin by extracts of rooibos (Aspalathus linearis) and honeybush (Cyclopia intermedia), unique South African herbal teas. Cancer Lett. 224:193-202.

Matteri, R. L., Klir, J. J., Fink, B. N. and Johnson, R. W. 1998. Neuroendocine-immune interactions in the neonate. Domest. Anim. Endocrinol. 15:397-407.

McCord, J. M. 2000. The evolution of free radicals and oxidative stress. Am. J. Med. 108:652-659.

Miyake, Y., Minato, K., Fukumoto, S., Yamamoto, K., Oya-Ito, T., Kawakishi, S. and Osawa, T. 2003. New potent antioxidative hydroxyflavanones produced with Aspergillus saitoi from flavanone glycoside in citrus fruit. Biosci Biotechnol Biochem. 67:1443-1450.

NRC. 1998. Nutrient Requirement of Pigs. 10th ed. National Research Council. Academy Press, Washington, DC.

Packer, L., Rimbach, G. and Virgili, F. 1999. Antioxidant activity and biologic properties of a procyanidin-rich extract from pine (pinus maritima) bark, pycnogenol. Free Radiac Biol. Med. 27:704-724.

Pendino, K. J., Laskin, J. D., Shuler, R. L., Punjabi, C. J. and Laskin, D. L. 1993. Enhanced production of nitric oxide by rat alveolar macrophages after inhalation of a pulmonary irritant is associated with increased expression of nitric oxide synthase. J. Immunol. 151:7196-7205.

Rice-Evans, C. A., Miller, N. J. and Pananga, G. 1996. Structureantioxidant activity relationship of flavonoids and phenolic acids. Free Radic Biol. Med. 20:933-956.

SAS Institute, 2008. SAS user's guide, Statistical Analysis System Inst. Inc Cary NC.

Staedler, J., Schmalix, W. A. and Doehmer, J. 1995. Inhibition of biotransformation by nitric oxide (NO) overproduction and toxic 
consequences. Toxicol. Lett. 82:215-219.

Terra, X., Valls, J., Vitrac, X., Mérrillon, J. M., Arola, L., Ardèvol, A., Bladé, C., Fernandez-Larrea, J., Pujadas, G., Salvadó, J. and Blay, M. 2007. Grape-seed procyanidins act as anti-inflammatory agents in endotoxin-stimulated RAW 264.7 macrophages by inhibiting NFkB signaling pathway. J. Agric. Food Chem. 55:4357-4365.

Touriño, S., Selga, A., Jiménez, A., Juliá, L., Lozano, C., Lizárraga, D., Cascante, M. and Torres, J. L. 2005. Procyanidin Fractions from Pine (Pinus pinaster) Bark: Radical Scavenging Power in Solution, Antioxidant Activity in Emulsion, and Antiproliferative Effect in Melanoma Cells. J. Agric. Food Chem. 53:4728-4735.

Vigna, G. B., Costantini, F., Aldini, G., Carini, M., Catapano, A., Schena, F., Tangerini, A., Zanca, R., Bombardelli, E., Morazzoni, P., Mezzetti, A., Fellin, R. and Facino, R. M. 2003. Effect of a standardized grape seed extract on low-density lipoprotein susceptibility to oxidation in heavy smokers. Metabolism. 52:1250-1257.

Virgili, F., Kobuchi, H. and Packer, L. 1998. Procyanidins extracted from pinus maritima $\left(\right.$ Pycnogenol $\left.^{\mathbb{B}}\right)$ : Scavengers of free radical species and modulators of nitrogen monoxide metabolism in activated murine RAW 264.7 Macrophages. Free Radi. Biol. Med. 24:1120-1129.

Warren, J. B. 1994. Nitric oxide and human skin blood flow response to acetylcholine and ultraviolet light. FASEB J. 8:247-251.

Webel, D. M., Finck, B. N., Baker, D. H. and Johnson, R. W. 1997. Time course of increased plasma cytokines, cortisol, and urea nitrogen in pigs following intraperitoneal injection of lipopolysaccharide. J. Anim. Sci. 75:1514-1520.

Wilson, H. K., Price-Jones, C. and Hughes, R. E. 1976. The influence of an extract of orange peel on the growth and ascorbic acid metabolism of young guinea-pigs. J. Sci. Food Agric. 27:661-666.

Wright, K. J., Balaji, R., Hill, C. M., Dritz, S. S., Knoppel, E. L. and Minton, J. E. 2000. Intergrated adrenal, somatotropic, and immune response of growing pigs to treatment with lipopolysaccharide. J. Anim. Sci. 80:2619-2682.

Zhishen, J., Tang, M. C. and Wu, J. M. 1999. The determination of flavonoid contents in mulberry and their scavenging effects on superoxide radicals. Food Chem. 64:555-559.

(Received May 13, 2013; Accepted Jun. 13, 2013) 